\title{
Erratum
}

\section{Loss Coverage: Why Insurance Works Better with Some Adverse Selection, Edited by R. Guy Thomas, Cambridge: Cambridge University Press, 2018, 274pp, ISBN: 978-1-107- 49590-6 - ERRATUM}

\section{Michael Hoy}

https://doi.org/10.1017/S174849951800026X Published online by Cambridge University Press 28 August 2018

\section{Keywords}

Erratum

An error was made in the title of the aforementioned book review for which we apologise. The review originally stated incorrectly that Loss Coverage: Why Insurance Works Better with Some Adverse Selection was edited by R. Guy Thomas. It was in fact written by him.

\section{Reference}

Hoy, Michael. "Loss Coverage: Why Insurance Works Better with Some Adverse Selection, Edited by R. Guy Thomas, Cambridge: Cambridge University Press, 2018, 274pp, ISBN: 978-1-10749590-6.” Annals of Actuarial Science (2018), 1-6. doi:10.1017/S174849951800026X. 